\title{
Total public service output, inputs and productivity
}

Mike G Phelps, Sophia Kamarudeen, Katherine Mills and Richard Wild

Office for National Statistics

\section{Summary}

In 2008, public services accounted for approximately 22 per cent of the expenditure measure of Gross Domestic Product (GDP) in the UK. Given the Government's announced intention to cut government spending and given that almost everyone is a potential user of public services such as the NHS or schools there is a particular concern about 'what we are getting for our money'. One important aspect of this, though not the only aspect, is productivity: the quantity of output that is produced divided by the quantity of input used. The Office for National Statistics (ONS) has published periodic assessments of the productivity performance of key public services. This article updates the experimental estimates for all public services which were produced last year (Phelps 2009).

\section{Introduction}

Figure 1 shows the year-on-year growth in overall output, inputs and productivity ${ }^{1}$. Key points to note are that:

on inputs

- annual input growth, that is growth in the quantity of labour, materials and capital assets used in production, was at an annual average rate of 3.2 per cent over the whole period

- the annual rate of growth in inputs rose from a low point of 1.0 per cent in 1998 to a high of 6.0 per cent in 2002. Between 2002 and 2005 growth rates were at or above the whole period average

- rates fell every year between 2002 and 2007. In 2007 the annual rate was 1.2 per cent

- input growth rose again in 2008, though not back to the very high rates seen between 2002 and 2004

\section{on outputs}

- output, measured by activities performed together with some quality adjustments, grew over the whole period at an annual average rate of 2.9 per cent. Over the same period total GDP grew at an annual average rate of 2.7 per cent 
- output growth followed a similar profile to input growth, but when input growth was increasing the rate of output growth was generally lower, and as input growth rates fell, output growth rates fell less

- annual output growth was highest at 4.4 per cent in 2002, the same year that input growth was highest. Growth rates fell in subsequent years, reaching a low of 1.3 per cent in 2007

- in 2008 output growth rose compared to the low growth in 2007 , to 1.9 per cent but was still well below the growth rates between 2000 and 2004

\section{and on productivity}

- because inputs grew a little faster than output, productivity over the whole period fell, on average by 0.3 per cent a year

- with the exception of 1998 and 2001, productivity fell in each year until 2006

- in 2006 and 2007 annual productivity in total public services rose, by 0.7 per cent in 2006 and 0.1 per cent in 2007

- however, in 2008, although output growth rose, input growth was faster than output growth, so productivity fell by 0.9 per cent

- the largest annual falls in productivity were in 2002 and 2003, when productivity fell by 1.4 per cent in each year. These were the years when input growth and output growth were at their highest

\section{Figure $1 \quad$ Growth in total public service output, inputs and productivity, 1997-2008}

United Kingdom

Annual percentage change

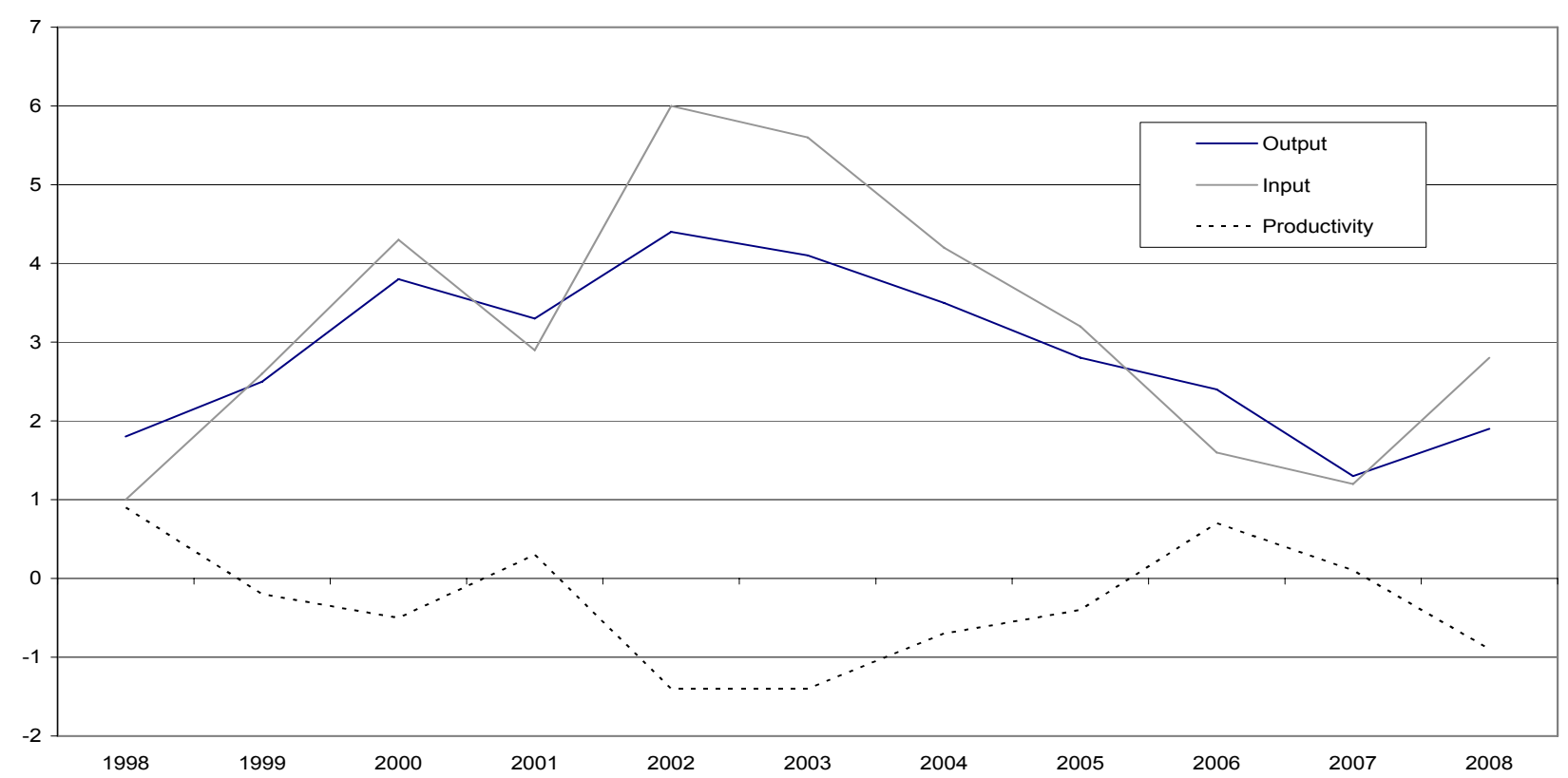

Source: Office for National Statistics 
All figures are based on the latest data available in May 2010. Some data for 2008 are partly forecast, because comprehensive measures of actual activity at the required level of detail (for example health procedures performed together with appropriate cost weights) are not yet available for $2008 / 09$.

Figure 2 shows, instead of the annual change, the index for output, inputs and productivity since 1997.

\section{Figure 2 Total public service output, inputs and productivity estimates}

United Kingdom

Index numbers 1997=100

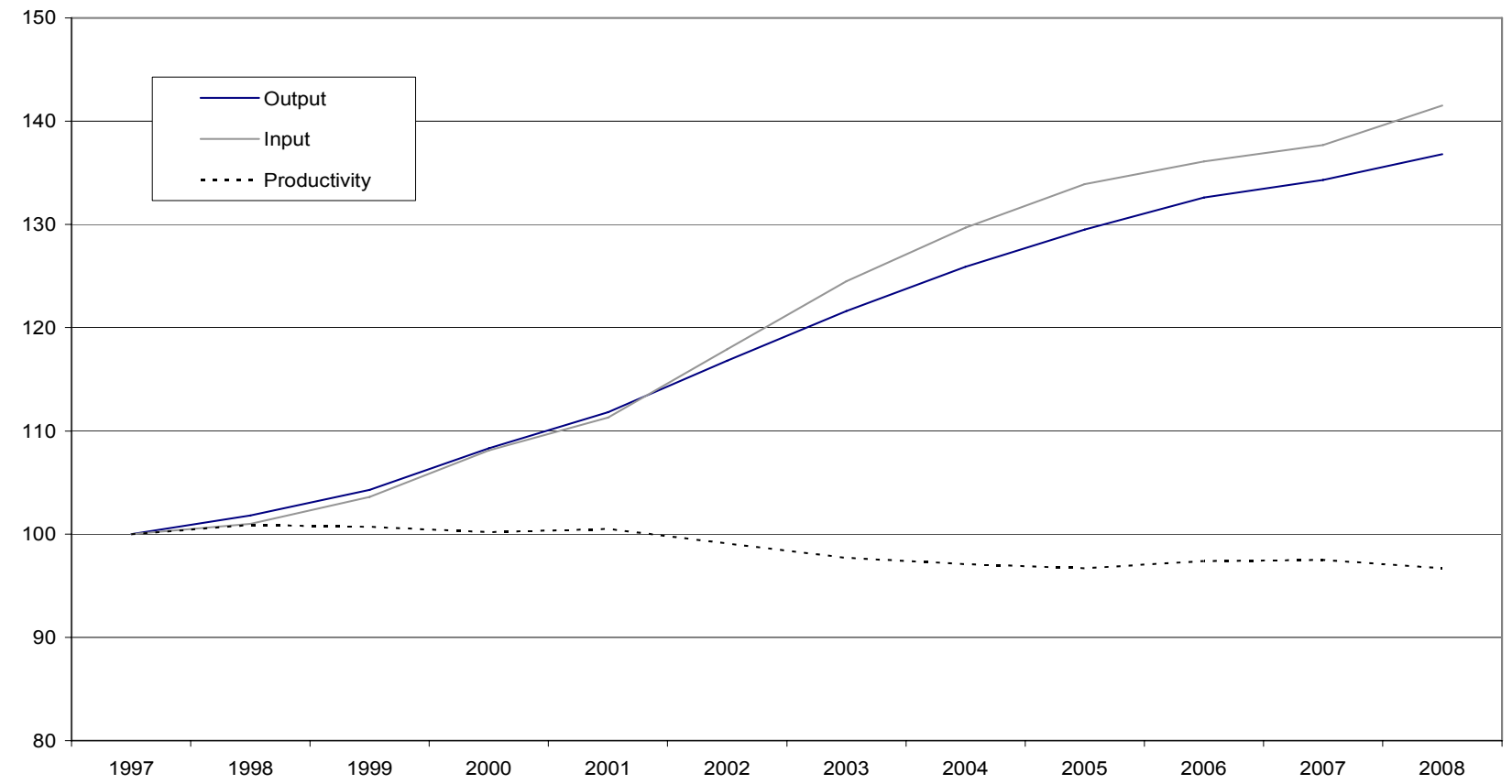

Source: Office for National Statistics

Key points to note are that:

- over the period 1997 to 2008 , the output of total public services rose by 36.8 per cent, an annual average rate of 2.9 per cent

- the volume of inputs used to provide these services grew by 41.5 per cent over the period, an annual average rate of 3.2 per cent

- as a result, the total public service productivity index fell over the period by 3.3 per cent, an annual average fall of 0.3 per cent

Measuring public service output presents special difficulties, particularly in taking adequate account of quality change. The methods are still being developed, so the estimates here are experimental statistics. For Healthcare and Education services, which account for half of all spending on public services, the estimates include an adjustment for quality. It has not yet been 
possible to develop satisfactory quality measures for the smaller spending areas. Absence of quality adjustment can lead to measured output falling if high cost activities are replaced by lower cost activities with improved or equivalent quality (or rising if the converse is true). Errors can also arise if there are changes in the characteristics of the population to whom services are delivered, for example, increasing levels of need of those in care homes.

\section{Background}

With increased attention being paid to what is actually provided by public spending it is important to explain how ONS measures the output of public services. There is (usually) no market for public services in which well-defined units of output are bought and sold for well-defined prices. So it is difficult to provide a measure of how much the quantity of service changes over time, or what 'price' should be used to value the quantity, to combine with other sectors of the economy in an overall output total. There is, however, information on the inputs (of labour, goods and services and capital) used to provide the services. The output of public services in the National Accounts, therefore, used to be measured by assuming that output growth was simply equal to the growth in inputs. However since 1998, some parts of public service output have been measured using direct measures of activity such as pupil attendance or health procedures performed as the units of output; and unit cost weights have been used instead of market prices to add the different measures of activity together.

In 2003, the then National Statistician commissioned Sir Tony Atkinson to conduct an independent review of the measurement of government inputs and output in the context of National Accounts (Atkinson 2005). The UK Centre for the Measurement of Government Activity (UKCeMGA) was launched within the ONS in July 2005 to take forward the Atkinson agenda and has since worked to improve measures of public service output. Productivity articles for individual services, have been published previously, and in June 2009 an article was published which brought together, for the first time since Sir Tony Atkinson's review, an overall assessment of the public services collectively. UKCeMGA now produces regular annual articles on productivity in Healthcare and Education, the two largest services, and an annual article assessing all the public services collectively. The first annual article on Education productivity was published in December 2009 (Wild et al. 2009); the first annual article on Healthcare in March 2010 (Penaloza et al. 2010). This is the second article on public service productivity as a whole, which also provides the latest estimates of productivity by broad service category.

For the purposes of this article, the public services fall into distinct categories:

- the majority (representing 64 per cent of the total by expenditure in 2008) have their output measured largely by direct output indicators

- the remainder are currently measured using the 'output = inputs' convention. That is, the output is deemed to be equal to the volume of the inputs used in generating the output 
The output of Healthcare, Education, Adult Social Care, Social Security Administration (SSA) and Public Order and Safety ${ }^{2}$ (POS) is measured directly, using measures of activity, quality adjusted in the case of Healthcare and Education. Children's Social Care uses direct measures for lookedafter children and indirect measures for the remainder such as preventative services. The output measurements are for the whole of the UK. However, in some areas it has not yet been possible to directly measure the output in Northern Ireland, Scotland or Wales. For example, the measure of Healthcare activity only uses data for England, Wales and Northern Ireland. In such cases the output index for each service refers to what is measured directly, but the weights used to combine different services into the overall total reflect total UK spending on each service. ONS is working with the Devolved Administrations to improve coverage further.

The services for which the 'output=inputs' convention is used include those services provided collectively to all national residents. The most important of these are the services of the Police and Defence. This is in line with current international National Accounts guidance for collective services. The 'output=inputs' convention is also used for the 'Other'3 category. In some cases, development work is under way to generate direct measures of output for services currently subject to the 'output=inputs' convention. However, that work has not yet reached fruition. The implication of this approach is that productivity for such services is always unchanged.

In large part, the methods underpinning these estimates have been accepted for use in the National Accounts, following ONS' normal rigorous methods approval processes. So the associated estimates themselves are also the ones implicit in the National Accounts. However, there are some exceptions:

- not all of the relevant methods have yet completed the National Accounts approval process. These include quality adjustments for Healthcare and Education, a new measure for labour inputs to defence, new output measures for Prisons, Probation and Children's Social Care.

- in the National Accounts, Further Education is included in the final consumption spending of the Non-Profit Institutions Serving Households (NPISH) sector, not the General Government sector. But most of Further Education for under-19s is funded by public sector grants. This article, therefore, includes estimates for Further Education for under-19s ${ }^{4}$

\section{Estimate of the volume of output}

\section{What is being measured?}

This section reports estimates of the growth in the output of public services from 1997 to 2008. It uses the most up-to-date methods and quality adjustments, whether in National Accounts or still in development. More detail on the output measures can be found in the relevant productivity articles produced by UKCeMGA. For Healthcare see Penaloza et al. (2010), Education (Wild et al. 2009), Adult Social Care (ONS 2007), and SSA (ONS 2008). Methods have recently been improved for Prisons (Baird and Rowlinson 2010), for Probation (Baird 2010) and Children's Social Care (Phelps 2010a).

Estimates used are the latest available as at May 2010. Healthcare output for 2008 is thus a forecast based on only the first quarter of 2008 (the remaining quarters falling in the subsequent 
financial year). The next Healthcare productivity article will incorporate estimates based on the full calendar year. In some other areas the 2008 estimates are also partly forecast. Output data for all areas starts in 1997 because that is the earliest date for which the latest data delivered to Eurostat broken down by Classification of Functions of Government (COFOG) for inputs (ONS 2009) are available on a consistent basis.

\section{What is included and how are the parts combined?}

The different individual service output indices are combined together into a single overall index using weights based on relevant service spending as a proportion of total General Government Final Consumption Expenditure (GGFCE), plus that part of Further Education dealing with under19s (GGFCEplusFE).

\section{Table $1 \quad$ General government final consumption expenditure weights by service ${ }^{1}, 1997-2008$}

United Kingdom

Percentages

\begin{tabular}{|c|c|c|c|c|c|c|c|c|c|c|}
\hline & Healthcare & Education & $\begin{array}{c}\text { Adult } \\
\text { social care }\end{array}$ & $\begin{array}{l}\text { Social security } \\
\text { administration s }\end{array}$ & $\begin{array}{l}\text { Children's } \\
\text { social care }\end{array}$ & $\begin{array}{l}\text { Public } \\
\text { order \& } \\
\text { safety }\end{array}$ & Police & Defence & Other & Total \\
\hline 1997 & 27.6 & 18.9 & 5.8 & 2.2 & 1.9 & 4.3 & 5.5 & 15.1 & 18.8 & 100 \\
\hline 1998 & 28.3 & 19.0 & 5.9 & 2.1 & 1.9 & 4.2 & 5.5 & 14.3 & 18.7 & 100 \\
\hline 1999 & 28.7 & 19.1 & 5.9 & 2.2 & 2.0 & 4.5 & 5.3 & 13.1 & 19.1 & 100 \\
\hline 2000 & 28.4 & 19.1 & 6.0 & 2.3 & 2.0 & 4.7 & 5.2 & 13.5 & 18.8 & 100 \\
\hline 2001 & 28.8 & 19.6 & 5.9 & 1.9 & 2.1 & 4.5 & 5.6 & 12.4 & 19.2 & 100 \\
\hline 2002 & 29.0 & 19.7 & 6.1 & 1.8 & 2.1 & 4.4 & 5.6 & 12.3 & 18.9 & 100 \\
\hline 2003 & 29.3 & 19.2 & 6.3 & 2.2 & 2.2 & 4.5 & 5.5 & 12.4 & 18.4 & 100 \\
\hline 2004 & 29.8 & 18.9 & 6.5 & 2.0 & 2.3 & 4.5 & 5.5 & 11.6 & 18.8 & 100 \\
\hline 2005 & 30.1 & 19.3 & 6.5 & 2.0 & 2.3 & 4.5 & 5.5 & 11.4 & 18.5 & 100 \\
\hline 2006 & 31.0 & 19.1 & 6.4 & 1.7 & 2.4 & 4.3 & 5.4 & 11.5 & 18.2 & 100 \\
\hline 2007 & 31.5 & 19.6 & 6.4 & 1.6 & 2.4 & 4.3 & 5.5 & 10.7 & 18.1 & 100 \\
\hline 2008 & 31.6 & 20.1 & 6.4 & 1.6 & 2.4 & 4.3 & 5.2 & 11.0 & 17.4 & 100 \\
\hline
\end{tabular}

Source: Office for National Statistics

1. Includes that part of Further Education dealing with under-19s

Table 1 illustrates movements in these proportions between 1997 and 2008. The most notable change is the rise in the share of Healthcare spending from 27.6 per cent of the total in 1997 to 31.6 per cent in 2008 (with most of the rise occurring between 1997 and 2006), broadly matched by the fall in the share of Defence spending from 15.1 per cent to 11.0 per cent over the same period. The share of Education spending also rose, from 18.9 per cent in 1997 to 20.1 in 2008 , with 
most of the rise in 2007 and 2008. Elsewhere there were rises of approximately half a percentage point in the share of both Adult and Children's Social Care, and a fall in the share of spending on Social Security Administration, Public Order and Safety and Other.

The breakdown of the 2008 values is illustrated in Figure 3. Healthcare is the largest identified component of GGFCEplusFE, followed by Education and Defence. Adult Social Care, POS and Police also account for substantial proportions of GGFCEplusFE. There is also a substantial 'Other' category.

\section{Figure 3 General government final consumption expenditure weights by service, 2008}

United Kingdom

Percentages

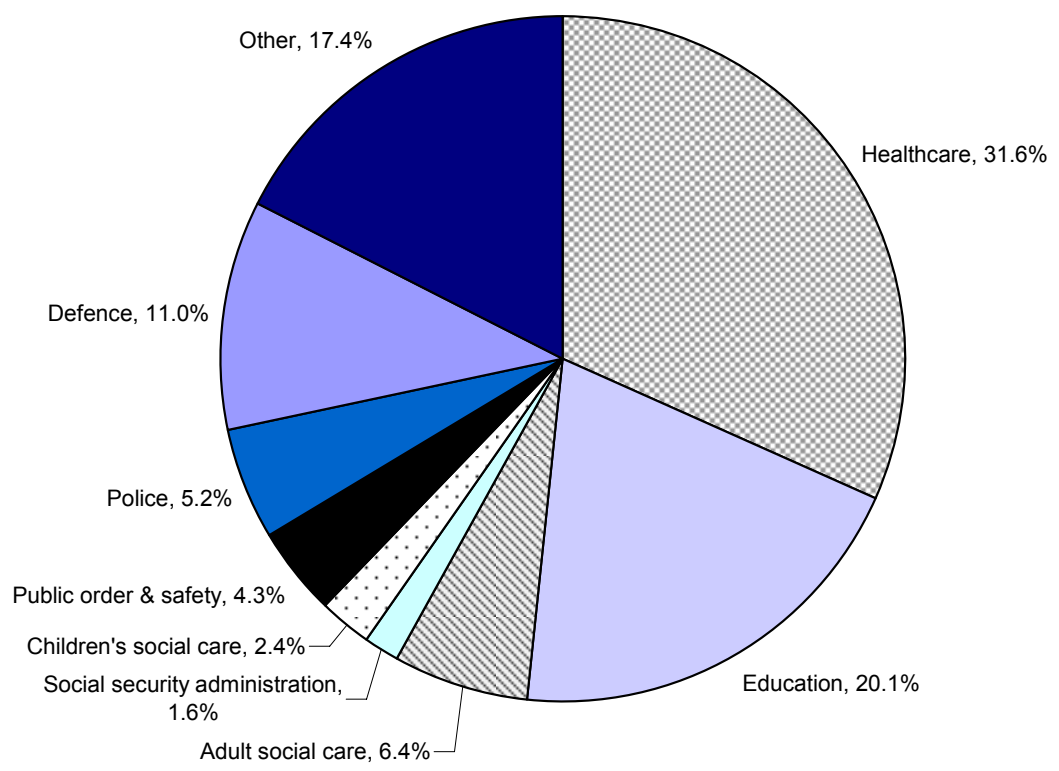

Source: Office for National Statistics

\section{What measures of output are used?}

Most of the direct measures are cost weighted activity indices. For example, Healthcare output largely consists of activities divided into Healthcare Resource Groups (HRGs) - health procedures of a similar type, and in Education the basic unit is pupil attendances. 


\section{Which areas are quality-adjusted?}

The output figures for Education are quality-adjusted using GCSE scores (Standard grades in Scotland) over the whole period (Wild et al. 2009). The Healthcare output figures are qualityadjusted for the period 2001 to 2008 (using an estimate for 2008). The overall adjustment incorporates adjustments for patient experience, reflecting how patients are treated; clinical outcomes in general practice; and health effects, measuring impact in terms of life expectancy, health gains, survival rates and waiting times (Penaloza et al. 2010).

There are no further quality adjustments. For certain areas this is likely to lead to underestimation of output. For example, education may lead to improved wider outcomes that a simple GCSEadjusted pupil attendance measure cannot capture, such as improved child health or improved outcomes in later life not related to exam attainment.

\section{How much has overall output grown?}

Figure 4 shows the year-on-year growth in overall output.

\section{Figure 4 Growth in total public service output, 1997-2008}

United Kingdom

Percentages

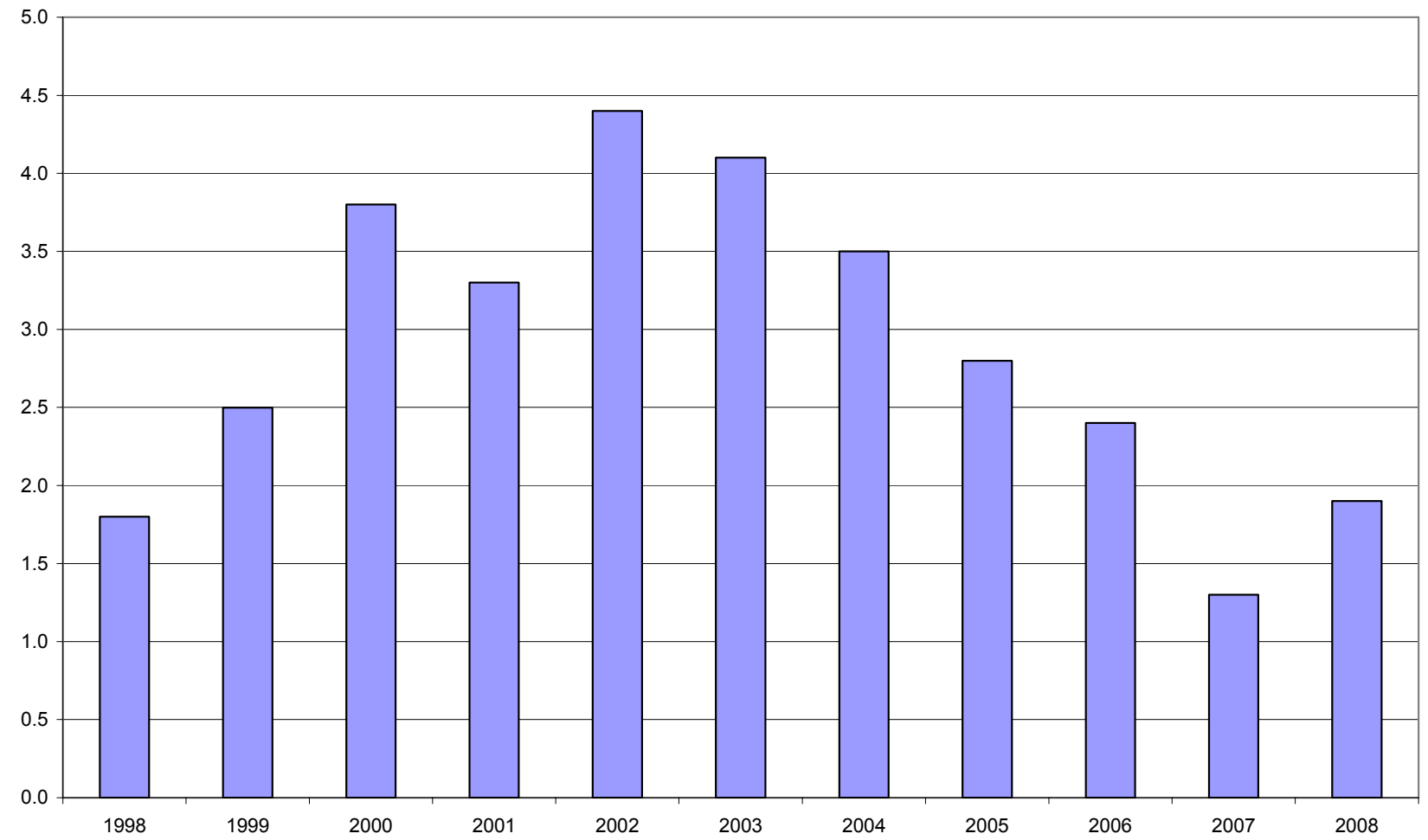

Source: Office for National Statistics 
Key points to note are:

- from 1997 to 2008, the total public service output index increased by 36.8 per cent (see table 2.2), an average of 2.9 per cent a year

- from 2000 to 2004 annual growth was always above the average of 2.9 per cent, and below the average in all other years

- output growth was particularly high in 2002 and 2003 with annual growth of 4.4 per cent and 4.1 per cent respectively

- from the peak in 2002 growth slowed in every year to 2007, where it reached 1.3 per cent

- in 2008 growth rose again, to 1.9 per cent, still below the average for the whole period

\section{Which services grew fastest?}

Table 2 shows the index of outputs for each service and for total public services. The last row of the table shows the mean annual average growth rates over the whole period.

\section{Table 2 Total public service output estimates by service, 1997- 2008}

United Kingdom

Index numbers 1997=100 and mean annual percentage change

\begin{tabular}{cccccccccccc}
\hline & & & \multicolumn{1}{c}{$\begin{array}{c}\text { Adult } \\
\text { social } \\
\text { care }\end{array}$} & $\begin{array}{c}\text { Social security Children's } \\
\text { administration social care }\end{array}$ & $\begin{array}{c}\text { Public } \\
\text { order \& } \\
\text { safety }\end{array}$ & Police & Defence & Other & Total \\
\hline 1997 & 100.0 & 100.0 & 100.0 & 100.0 & 100.0 & 100.0 & 100.0 & 100.0 & 100.0 & 100.0 \\
1998 & 103.9 & 103.1 & 102.4 & 98.4 & 118.9 & 101.3 & 99.6 & 96.3 & 101.2 & 101.8 \\
1999 & 107.4 & 106.5 & 101.6 & 97.5 & 136.7 & 102.5 & 98.5 & 91.9 & 108.4 & 104.3 \\
2000 & 112.7 & 108.4 & 102.6 & 96.1 & 151.0 & 103.0 & 98.0 & 98.4 & 113.3 & 108.3 \\
2001 & 118.8 & 110.2 & 104.5 & 94.3 & 166.9 & 106.2 & 99.9 & 94.7 & 121.7 & 111.8 \\
2002 & 124.9 & 113.4 & 112.0 & 94.6 & 179.1 & 104.2 & 103.4 & 100.5 & 127.5 & 116.8 \\
2003 & 131.7 & 115.3 & 116.1 & 97.1 & 188.2 & 107.2 & 108.4 & 107.9 & 131.2 & 121.6 \\
2004 & 138.2 & 117.7 & 118.8 & 100.5 & 193.8 & 104.8 & 113.2 & 106.9 & 141.2 & 125.9 \\
2005 & 145.1 & 120.7 & 120.1 & 97.1 & 197.7 & 105.3 & 115.5 & 107.6 & 145.5 & 129.5 \\
2006 & 150.2 & 123.2 & 121.4 & 98.4 & 197.1 & 106.3 & 118.2 & 111.7 & 147.4 & 132.6 \\
2007 & 156.1 & 126.3 & 118.8 & 98.0 & 199.3 & 106.7 & 120.0 & 107.2 & 147.9 & 134.3 \\
2008 & 162.7 & 128.8 & 114.8 & 102.8 & 192.4 & 108.8 & 118.7 & 111.5 & 147.3 & 136.8 \\
\hline Mean(\%) & 4.5 & 2.3 & 1.3 & 0.3 & 6.1 & 0.8 & 1.6 & 1.0 & 3.6 & 2.9 \\
\hline
\end{tabular}

Source: Office for National Statistics 
Key points to note are:

- over the whole period 1997-2008, Children's Social Care grew the fastest, by 92.4 per cent in total, an annual average of 6.1 per cent

- Healthcare output had the next highest growth. Over the whole period it grew by 62.7 per cent, with an annual average growth of 4.5 per cent

- the omnibus 'Other' category, including for example Environmental Protection and General Public Services, grew in total by 47.3 per cent, an annual average of 3.6 per cent

- Children's Social Care, Healthcare and 'Other' were the only services whose output grew faster than the public service total

- over this period GDP as a whole grew at an annual average rate of 2.7 per cent

- there was one more service which grew faster than GDP, though more slowly than public services in total. This was Education, whose output grew in total by 28.8 per cent, an annual average growth of 2.3 per cent. Education output is strongly affected by the number of school age children, which has been little changed over the period, though academic attainment has improved

- the output of all the remaining categories grew, though more slowly

- the below average growth of Adult Social Care may reflect the failure of the measure to account for an increasingly complex case mix and a shift from residential care to cheaper care provided at home

\section{Contributions to growth}

The fastest growing individual services do not necessarily make the biggest difference to the total growth of all the services, because they may only account for a small share in the total when weighted by expenditure. Figure 5 shows the contribution each service makes to the growth in the total between 1997 and 2008, taking account of its individual share as well as its individual growth rate.

Of the total 36.8 percentage change:

- Healthcare made the largest contribution of 17.1 percentage points, almost half the total, reflecting both its large share in the total and its high individual growth rate

- the next largest contribution is the omnibus 'Other' category, with 8.4 percentage points

- Education contributed 5.7 percentage points, reflecting its relatively large share

- the remaining services made small contributions of 1.6 percentage points or less

- the low share of Children's Social Care in total spending offsets its high individual growth rate, such that it contributes 1.5 percentage points to the total 


\section{Figure $5 \quad$ Contribution to growth in total public service output by service, 1997-2008}

United Kingdom

Percentage points

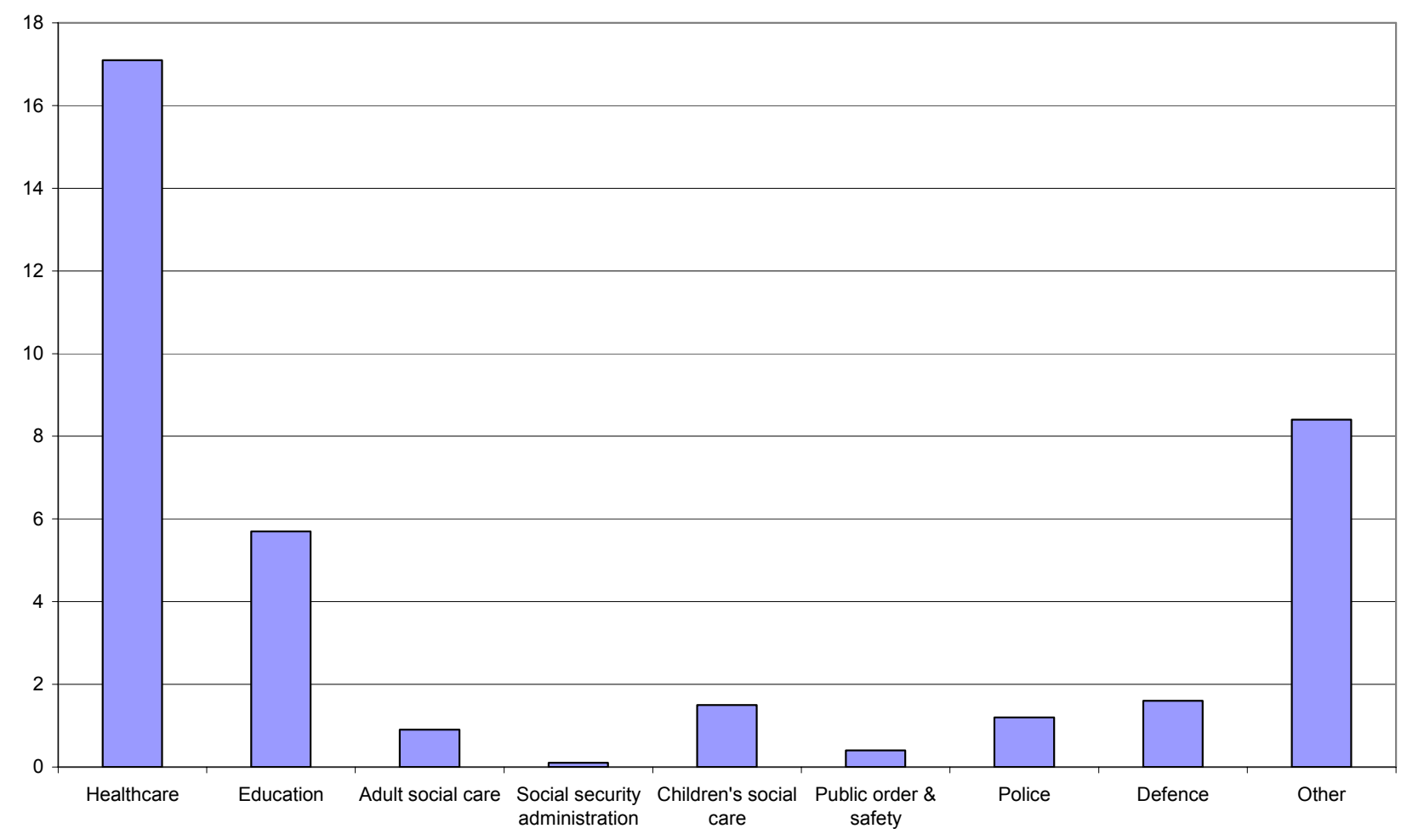

Source: Office for National Statistics

\section{Estimates of the volume of inputs}

\section{What is being measured?}

This section reports estimates of the growth in the volume of inputs used in providing public services: that is the amount of quality-adjusted labour, goods and services and capital (usually capital consumption). Within each category different kinds of input, for example teachers and teachers' assistants, are calculated separately and weighted together using appropriate weights to account for the differences in 'quality'. An overall index of inputs to public services as a whole is calculated by combining the various inputs using the proportions of expenditure in Table 1 as weights.

Input should ideally be measured directly (OECD 2001), for example, using hours worked or a measure of staff numbers in the case of labour input. Where data do not allow for a direct measure of inputs a volume measure can be derived by dividing a figure for the value of spending on an input by an appropriate estimate of the price of the input (the deflator) ${ }^{5}$. 
For the services where output was assumed to be the same as inputs, inputs were usually measured by deflating relevant expenditure by some appropriate price index. However, in some areas, notably defence labour, inputs are measured directly. ONS has recently published new estimates of defence labour inputs (Kamarudeen 2010) based on differentiating labour inputs. These are included in this article.

\section{How much have inputs grown?}

Figure 6 shows the year-on-year growth in overall inputs.

\section{Figure $6 \quad$ Growth in total public service inputs, 1997-2008}

\section{United Kingdom}

Percentages

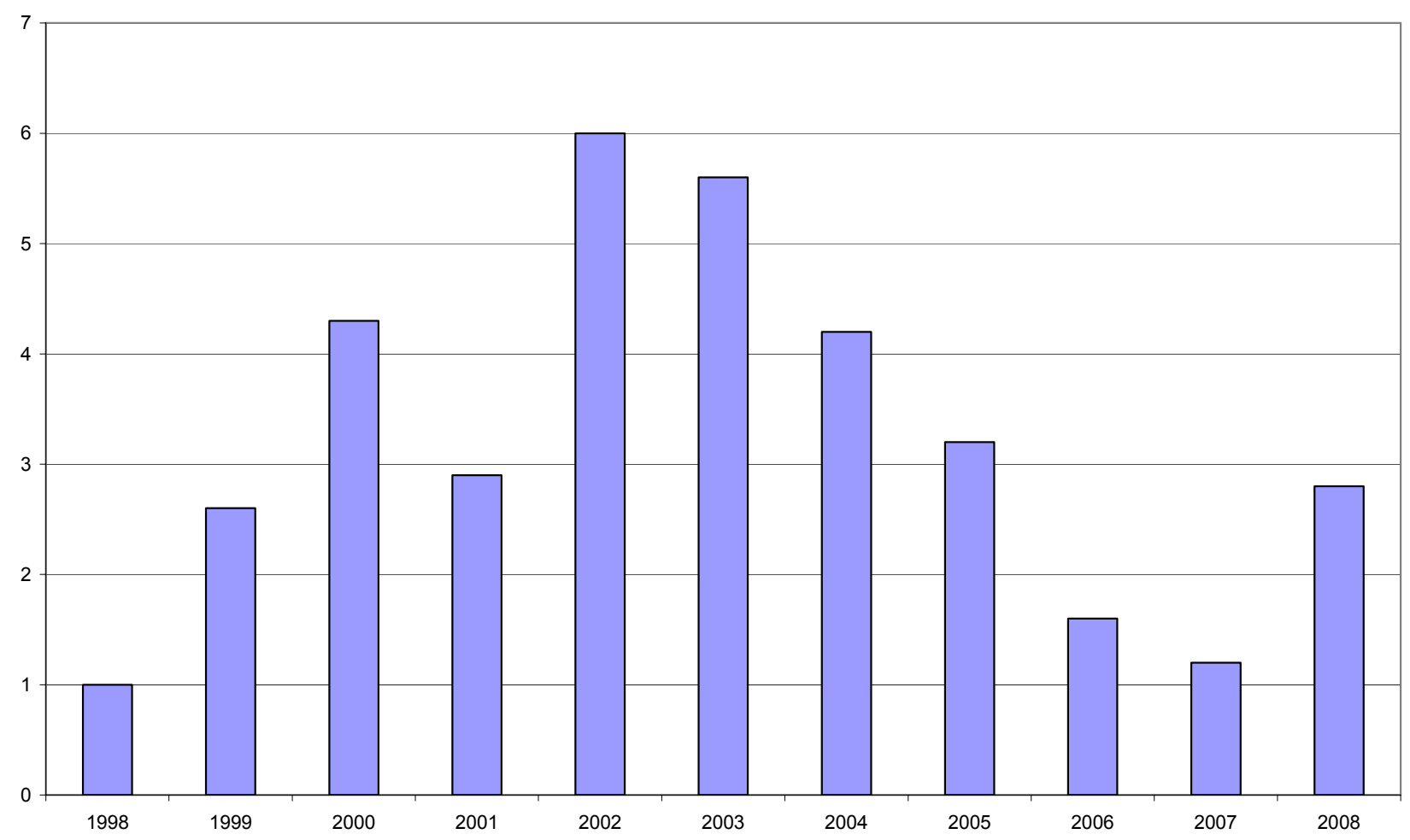

Source: Office for National Statistics

Key points to note are that:

- over the period 1997 to 2008, the volume of total public service inputs increased by 41.5 per cent (see table 3.1), an annual average increase of 3.2 per cent

- over the same period GDP grew at an annual average rate of 2.7 per cent

- input growth was particularly high in 2002 and 2003, with annual growth rates of 6.0 per cent and 5.6 per cent respectively, but was on or above average in every year between 2000 and 2005, apart from 2001

- input growth reduced from its peak in 2002 in each succeeding year until 2007, when input growth was 1.2 per cent 
- in 2008 input growth picked up again, to 2.8 per cent, but remained below the overall average

\section{In which services did inputs grow fastest?}

Table 3 shows the index of inputs for each service and for total public services. The last row of the table shows the annual growth rates over the whole period.

\section{Table 3 Total public service inputs estimates by service, 1997-2008} United Kingdom

Index numbers 1997=100 and mean annual percentage change

\begin{tabular}{|c|c|c|c|c|c|c|c|c|c|c|}
\hline & Healthcare & Education & $\begin{array}{l}\text { Adult } \\
\text { social } \\
\text { care }\end{array}$ & $\begin{array}{l}\text { Social security } \\
\text { administration }\end{array}$ & $\begin{array}{l}\text { Children's } \\
\text { social care }\end{array}$ & $\begin{array}{l}\text { Public } \\
\text { order \& } \\
\text { safety }\end{array}$ & Police & Defence & Other & Total \\
\hline 1997 & 100.0 & 100.0 & 100.0 & 100.0 & 100.0 & 100.0 & 100.0 & 100.0 & 100.0 & 100.0 \\
\hline 1998 & 104.4 & 101.3 & 100.7 & 95.2 & 104.8 & 95.7 & 99.6 & 96.3 & 101.2 & 101.0 \\
\hline 1999 & 107.5 & 102.4 & 104.0 & 102.5 & 118.1 & 104.8 & 98.5 & 91.9 & 108.4 & 103.6 \\
\hline 2000 & 113.2 & 104.2 & 106.2 & 108.1 & 122.0 & 113.5 & 98.0 & 98.4 & 113.3 & 108.1 \\
\hline 2001 & 118.0 & 108.5 & 108.7 & 95.8 & 128.3 & 112.4 & 99.9 & 94.7 & 121.7 & 111.3 \\
\hline 2002 & 126.7 & 114.3 & 117.6 & 97.2 & 139.4 & 118.2 & 103.4 & 100.5 & 127.5 & 117.9 \\
\hline 2003 & 135.7 & 116.4 & 127.0 & 122.4 & 153.7 & 124.9 & 108.4 & 107.9 & 131.2 & 124.5 \\
\hline 2004 & 142.4 & 120.7 & 132.9 & 113.5 & 166.4 & 131.6 & 113.2 & 106.9 & 141.2 & 129.7 \\
\hline 2005 & 149.4 & 124.7 & 133.8 & 120.2 & 172.3 & 133.9 & 115.5 & 107.6 & 145.5 & 133.9 \\
\hline 2006 & 152.3 & 127.6 & 133.7 & 105.1 & 182.7 & 132.0 & 118.2 & 111.7 & 147.4 & 136.1 \\
\hline 2007 & 158.7 & 130.5 & 132.4 & 95.8 & 183.7 & 130.3 & 120.0 & 107.2 & 147.9 & 137.7 \\
\hline 2008 & 166.5 & 134.7 & 135.5 & 96.1 & 188.8 & 133.7 & 118.7 & 111.5 & 147.3 & 141.5 \\
\hline Mean(\%) & 4.7 & 2.7 & 2.8 & -0.4 & 5.9 & 2.7 & 1.6 & 1.0 & 3.6 & 3.2 \\
\hline
\end{tabular}

Source: Office for National Statistics

Key points to note are:

- inputs have risen fastest in the areas where output growth has also been the fastest, Children's Social Care and Healthcare

- Children's Social Care inputs increased by 88.8 per cent, an annual average of 5.9 per cent

- Healthcare inputs increased by 66.5 per cent, an annual average of 4.7 per cent

- these were the only directly-measured or partly directly-measured areas in which inputs increased faster than the public service average, though inputs increased in all areas

- in Social Security Administration inputs actually fell, by 3.9 per cent over the whole period, an annual average fall of 0.4 per cent 


\section{Contributions to growth}

As with output, the fastest growing individual services do not necessarily make the biggest differences to the total inputs growth of all the services, because they may only account for a small share in the total. Figure 7 illustrates the contribution each service makes to the growth in the total between 1997 and 2008, taking account of its individual share as well as its individual growth rate.

\section{Figure $7 \quad$ Contribution to growth in total public service inputs by service, 1997-2008}

United Kingdom

Percentage points

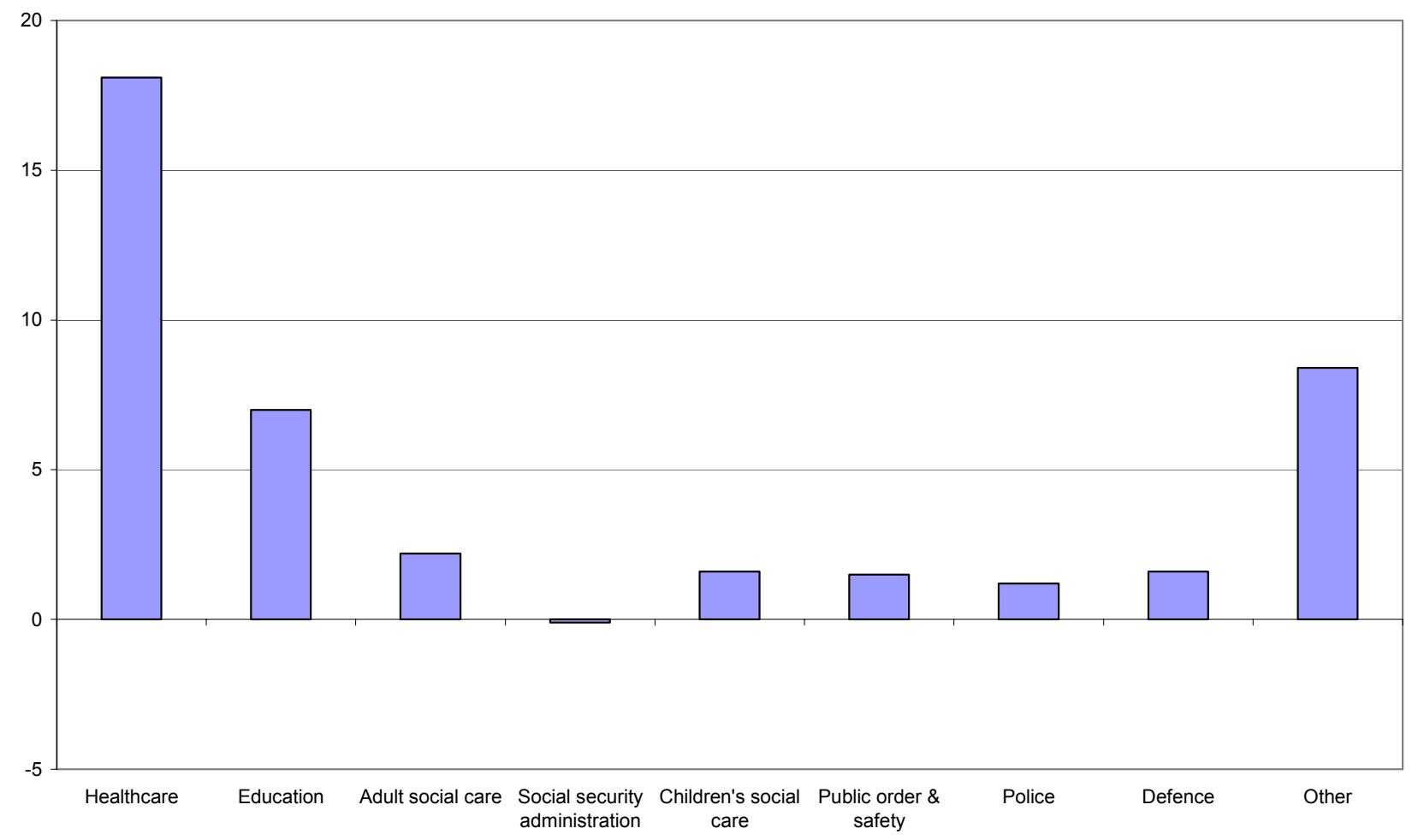

Source: Office for National Statistics

Of the growth in the total inputs index of 41.5 per cent:

- Healthcare contributed 18.1 percentage points, reflecting both the strong growth in inputs and the high share of total spending

- the 'Other' category contributed 8.4 percentage points

- Education contributed 7.0 percentage points, reflecting its relatively high share of total expenditure

- the remaining services all contributed relatively small amounts, 2.2 percentage points or less

- Social Security Administration actually made a small negative contribution of 0.1 percentage points, reflecting the overall fall in Social Security Administration inputs dampened by its small share in total spending 
- although inputs into Children's Social Care grew the fastest, its contribution to overall inputs growth was quite small (1.6 percentage points) because of its relatively small share in total expenditure

\section{Total productivity growth in public services}

\section{What is being measured?}

This section reports estimates of productivity. The productivity index is derived by dividing the index of output by the index of inputs and multiplying by 100; productivity change is then calculated using the periodic growth in this index. ${ }^{6}$ These estimates provide information relevant to the measurement of the efficiency with which public services are provided. However, they do not provide direct information on how far (if at all) public service productivity is below best practice (which would require systematic quantitative measures of best practice), or on how much of any productivity change is due to changes in the way services are provided (which would require an estimate of what would have happened if the changes had not been made).

More information on services can be found from other sources such as the reports of the National Audit Office. These offer some information relevant to the above questions. The individual articles on public service productivity from ONS include, in their sections on triangulation, discussions of studies relevant to productivity in the particular service.

The approach taken here is to account, as far as possible, for all inputs. Any changes in the index therefore reflect some combination of changes in the efficiency with which measured inputs are used, returns to scale (where the amount of inputs used per unit of output changes with the scale of inputs) and changes in unmeasured inputs. Note that increases in the quality of inputs, such as labour, will reduce this measure of productivity growth if output does not increase in proportion. This may be a particular problem if improved quality of input is expected to lead to an improved quality of output, which is not fully captured by existing measures. For example, using better trained teachers raises pupil attainment but only at some future date outside the time period covered as there may be lags between changes in inputs and resulting changes in output which may only become apparent over longer periods.

\section{Estimates of total public service productivity}

Figure 8 shows the year-on-year growth in overall productivity. 
Key points to note are that:

- over the period 1997 to 2008 , the total public service productivity index fell 3.3 per cent (see table 4.1 , an average of 0.3 per cent a year

- productivity fell most in 2002 and 2003, by 1.4 per cent in each year, and those were the years when inputs showed the fastest increases

- in 2006 productivity grew by 0.7 per cent and in 2007 by 0.1 per cent

- however in 2008 productivity fell by 0.9 per cent, as the rise in input growth outstripped the rise in output growth

Figure $8 \quad$ Growth in total public service productivity, 1997-2008 United Kingdom

Percentages

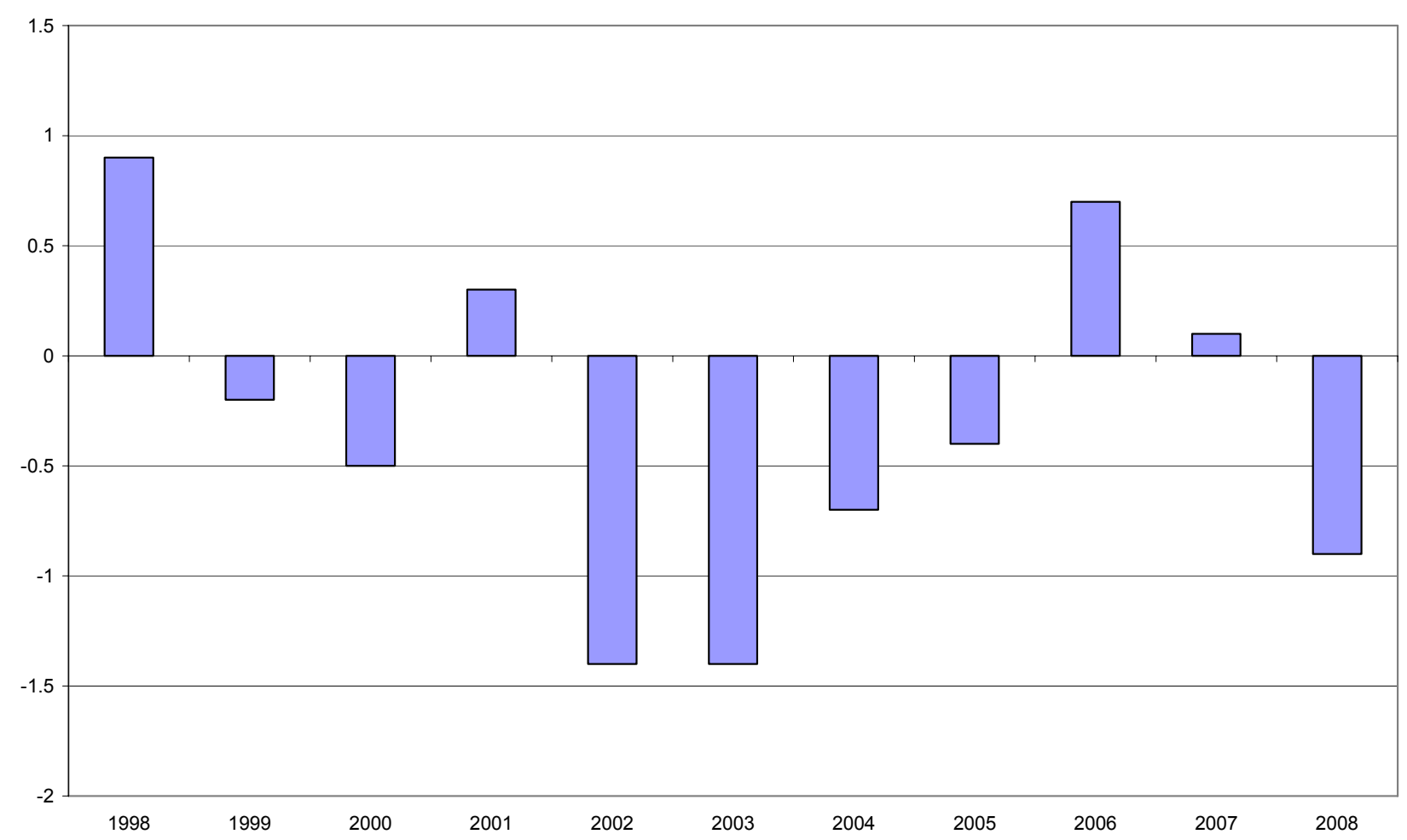

Source: Office for National Statistics

\section{How did productivity growth vary by service?}

Table 4 shows the index of productivity for each service and for total public services. The last row of the table shows the annual growth rates over the whole period. For services where 'output=inputs' productivity change, by definition, is always zero. 


\section{Table 4 Total public service productivity estimates by service, 1997-2008}

United Kingdom

Index numbers 1997=100 and mean annual percentage change

\begin{tabular}{|c|c|c|c|c|c|c|c|c|c|c|}
\hline & Healthcare & Education & $\begin{array}{l}\text { Adult } \\
\text { social } \\
\text { care }\end{array}$ & $\begin{array}{l}\text { Social security } \\
\text { administration }\end{array}$ & $\begin{array}{l}\text { Children's } \\
\text { social care }\end{array}$ & $\begin{array}{l}\text { Public } \\
\text { order \& } \\
\text { safety }\end{array}$ & Police & Defence & Other & Total \\
\hline 1997 & 100.0 & 100.0 & 100.0 & 100.0 & 100.0 & 100.0 & 100.0 & 100.0 & 100.0 & 100.0 \\
\hline 1998 & 99.5 & 101.7 & 101.7 & 103.3 & 113.4 & 105.8 & 100.0 & 100.0 & 100.0 & 100.9 \\
\hline 1999 & 100.0 & 104.0 & 97.7 & 95.1 & 115.7 & 97.9 & 100.0 & 100.0 & 100.0 & 100.7 \\
\hline 2000 & 99.5 & 104.1 & 96.6 & 88.9 & 123.7 & 90.8 & 100.0 & 100.0 & 100.0 & 100.2 \\
\hline 2001 & 100.6 & 101.5 & 96.1 & 98.5 & 130.1 & 94.6 & 100.0 & 100.0 & 100.0 & 100.5 \\
\hline 2002 & 98.6 & 99.3 & 95.3 & 97.3 & 128.4 & 88.2 & 100.0 & 100.0 & 100.0 & 99.1 \\
\hline 2003 & 97.1 & 99.1 & 91.5 & 79.4 & 122.4 & 85.8 & 100.0 & 100.0 & 100.0 & 97.7 \\
\hline 2004 & 97.1 & 97.5 & 89.4 & 88.5 & 116.4 & 79.6 & 100.0 & 100.0 & 100.0 & 97.1 \\
\hline 2005 & 97.1 & 96.8 & 89.8 & 80.8 & 144.7 & 78.6 & 100.0 & 100.0 & 100.0 & 96.7 \\
\hline 2006 & 98.6 & 96.5 & 90.8 & 93.6 & 107.9 & 80.6 & 100.0 & 100.0 & 100.0 & 97.4 \\
\hline 2007 & 98.3 & 96.8 & 89.7 & 102.3 & 108.5 & 81.9 & 100.0 & 100.0 & 100.0 & 97.5 \\
\hline 2008 & 97.7 & 95.7 & 84.7 & 107.0 & 101.9 & 81.4 & 100.0 & 100.0 & 100.0 & 96.7 \\
\hline Mean(\%) & -0.2 & -0.4 & -1.5 & 0.6 & 0.2 & -1.9 & 0.0 & 0.0 & 0.0 & -0.3 \\
\hline
\end{tabular}

Source: Office for National Statistics

Key points to note are that:

- productivity rose slightly in Children's Social Care, by 1.9 per cent, an annual average rise of 0.2 per cent, solely on the basis of what has happened in the looked-after children's sector, because the rest is indirectly measured and has a neutral effect on productivity

- productivity in Social Security Administration rose by 7 per cent over the period, an annual average rise of 0.6 per cent

- Healthcare productivity fell by 2.3 per cent, an annual average fall of 0.2 per cent

- Education productivity fell by 4.3 per cent, an annual average fall of 0.4 per cent

- Adult Social Care productivity fell by 15.3 per cent, an annual average fall of 1.5 per cent

- Public Order and Safety productivity fell by 18.6 per cent, an annual average fall of 1.9 per cent

- for Police, Defence and 'Other' services productivity was unchanged since 'output=inputs'

\section{Contributions to growth}

Figure 9 illustrates how much each service contributed to the total change in productivity between 1997 and 2008, taking account of both how much productivity in the service itself has changed and how important the service is in the total. 


\section{Figure 9 Contributions to growth in total public service productivity by service, 1997-2008}

United Kingdom

Percentage points

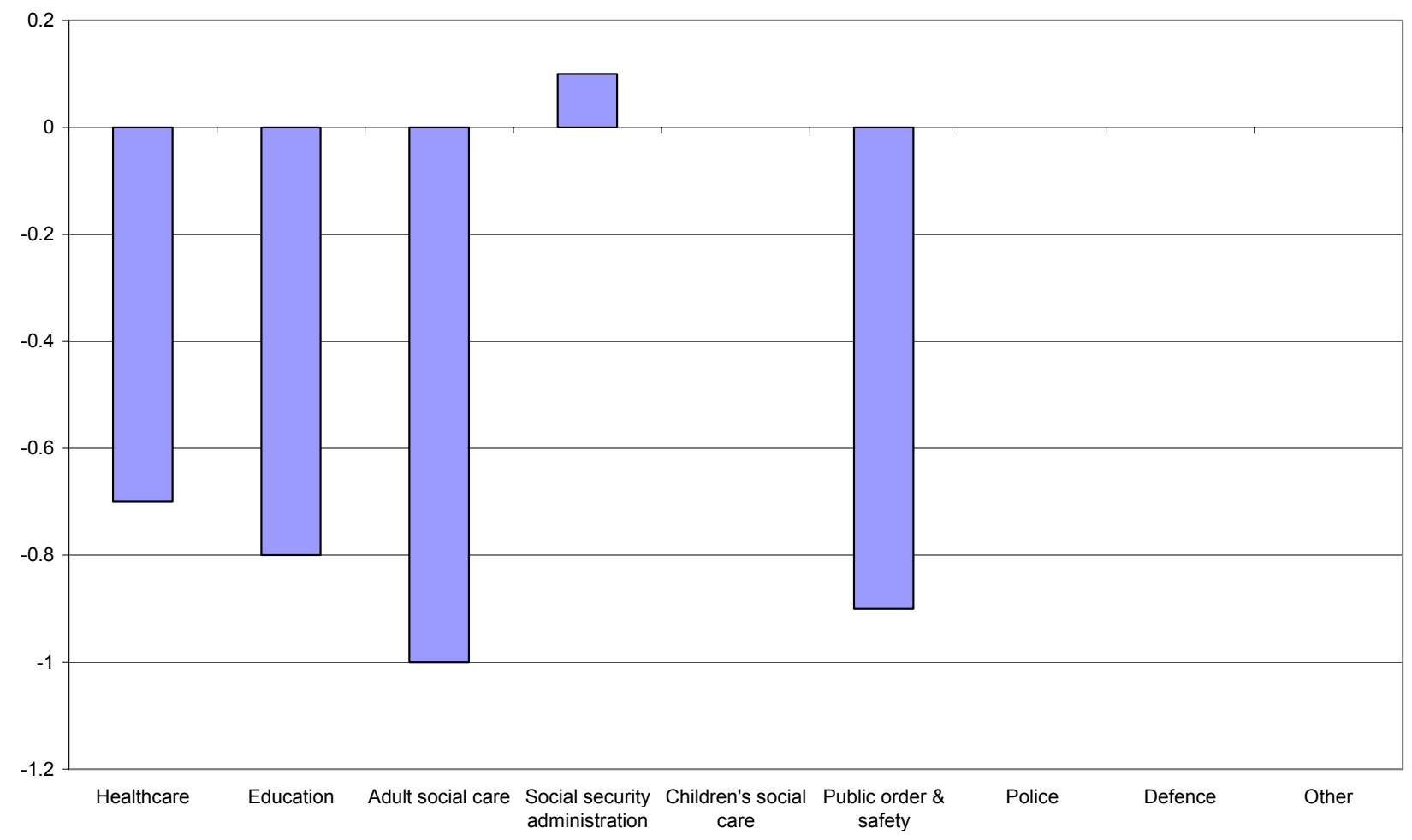

Source: Office for National Statistics

In summary:

- Adult Social Care made the largest contribution, of 1.0 percentage points to the overall fall of 3.3 per cent, though this may reflect the fact that the measure is not quality adjusted

- Public Order and Safety contributed 0.9 percentage points. Again the existing measures in this area are relatively undeveloped and some of this fall may reflect the difficulties in constructing the output measures, as discussed in Section 5.4 below

- Education contributed a fall of 0.8 percentage points, more or less in line with its expenditure share

- Healthcare contributed 0.7 percentage points, less than in proportion to its share of expenditure, reflecting the fact that healthcare productivity has fallen less than the public service average

- Children's Social Care, using the new measure makes no difference to overall productivity

- Social Security Administration offsets the overall fall, by 0.1 percentage points. Its small share in spending offsets the rather larger percentage rise in productivity

- Police, Defence and Other all make no contribution to overall productivity change because, by definition, productivity in these areas cannot change 


\section{Comparison with the National Accounts Blue Book 2009}

The estimates of output and input in this article are generally consistent with the Blue Book 2009. However there are some exceptions, particularly on the output side. The estimates of output are higher than the estimates in Blue Book. The major differences are:

- there is no quality adjustment for healthcare in the Blue Book, whereas this article includes a quality adjustment from 2001 which, on average, raises healthcare output growth by 0.4 percentage points a year

- the Blue Book has a multiplicative quality adjustment for Education, which increases output by 0.25 per cent a year, whereas this article uses an additive method which adds, on average, around 2.5 per cent a year to Education output

- the Blue Book 2009 does not include the experimental method for the output of Children's Social Care used in this article

- the Blue Book 2009 does not include the changes to the methods of measuring prisons and probation adopted here

Given that the output data in this article are higher than in Blue Book, the productivity estimates headlined in this article are higher than those implied by the Blue Book 2009.

\section{Revisions}

Figure 10 shows the revisions to the output series since the article published last year (Phelps 2009). Overall the series has changed very little.

Figure 10 Total public service output indices comparison, 1997-2007 United Kingdom

Annual percentage change

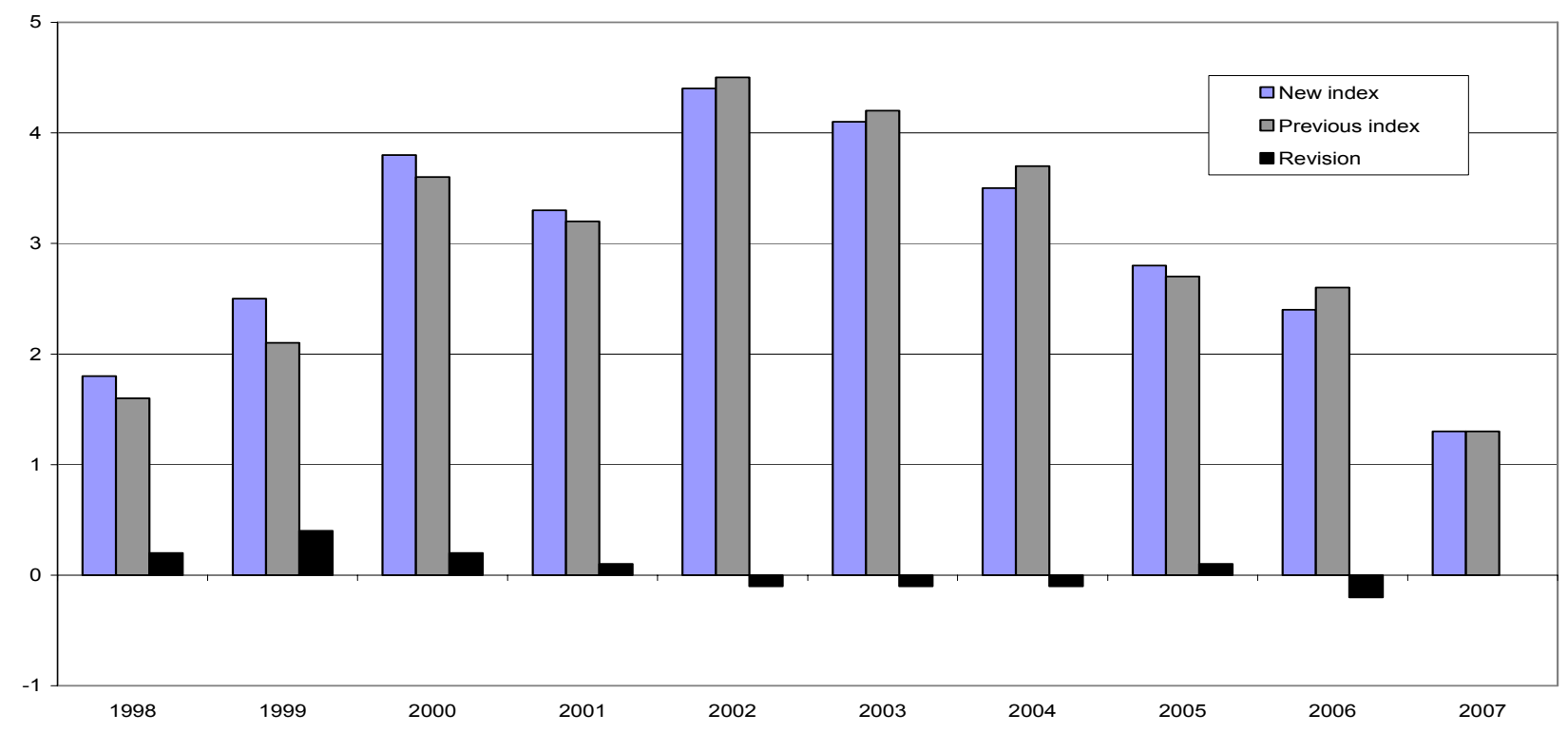


Figure 11 Total public service inputs indices comparison, 1997-2007 United Kingdom

Annual percentage change

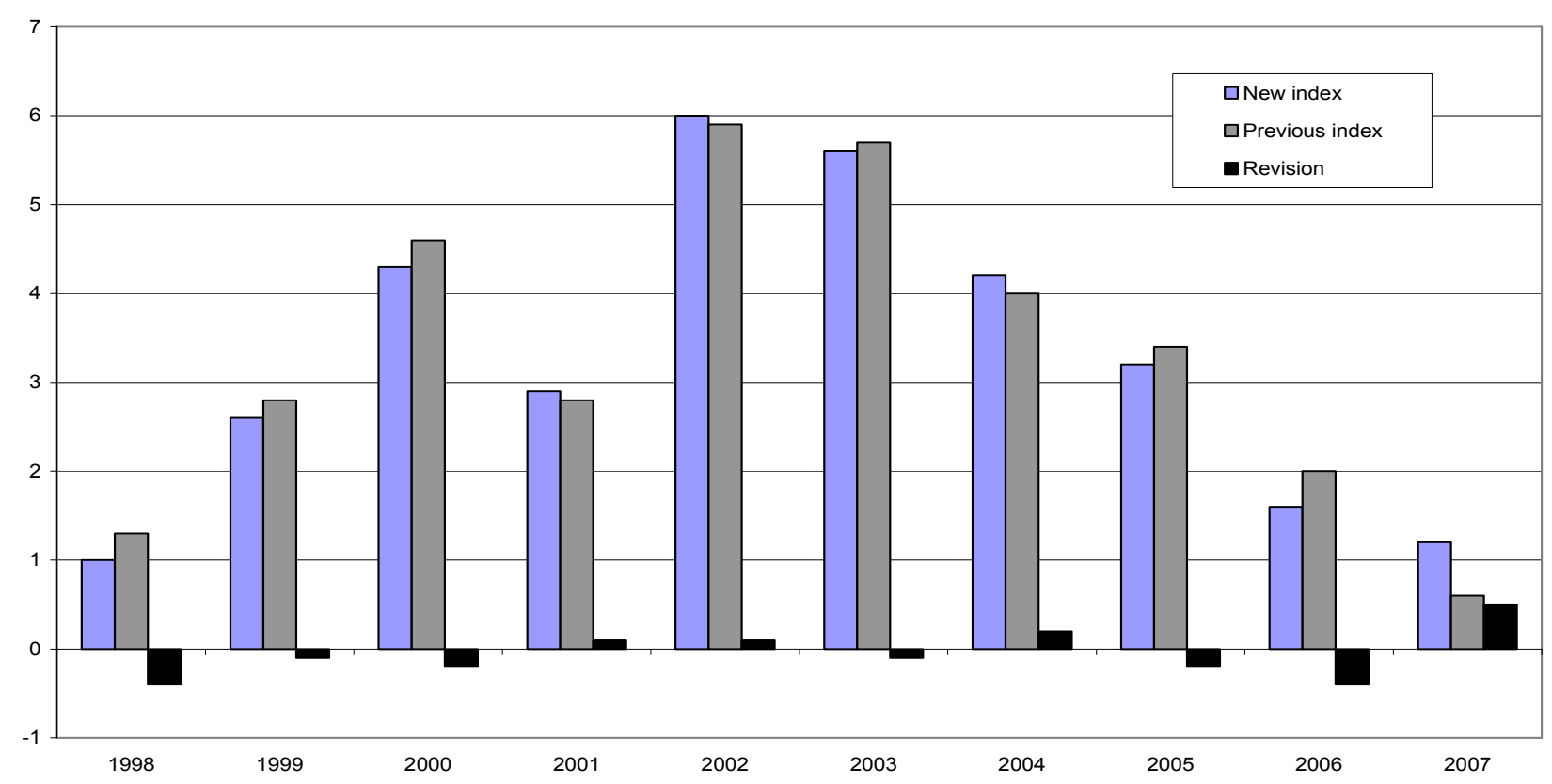

Source: Office for National Statistics

Figure 12 Total service productivity indices comparison, 1997-2007 United Kingdom

Annual percentage change

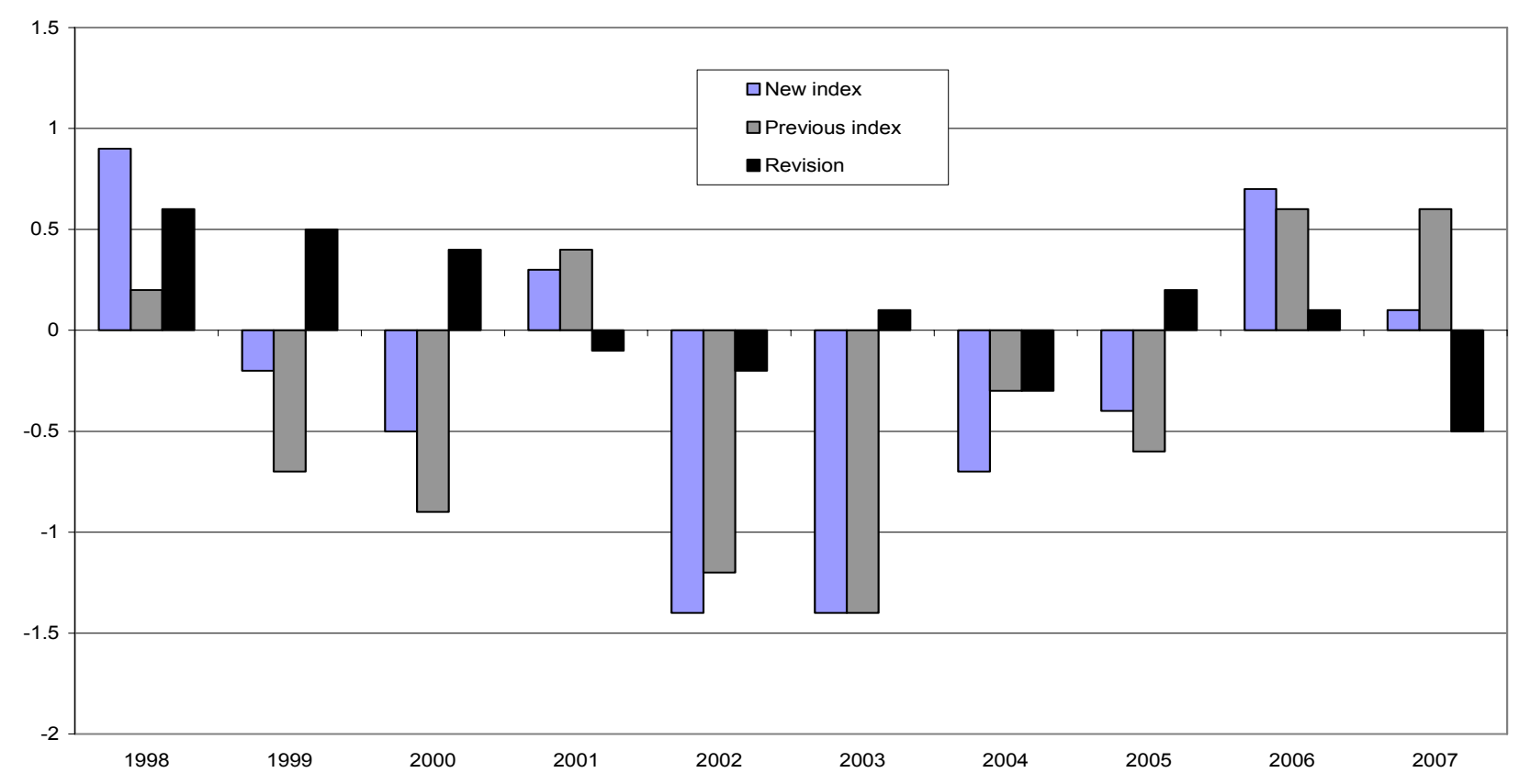

Source: Office for National Statistics 
Figure 11 shows the revisions to the input index since last year's article. Inputs growth has been revised down slightly, largely because of revisions to the underlying expenditure series and to some of the deflators. The net effect of these changes on productivity is very small, see Figure 12.

\section{Triangulation}

As well as the estimates for public service productivity published in this article ONS also produces experimental statistics of multi-factor productivity (MFP) for the whole economy and for some broad industrial groupings. The most recent estimate are in Long and Franklin (2010). The broad industrial groupings include the group of industries classified as Sections $L, M$, and $N$ (henceforth LMN): that is, public administration and defence (L), education (M) and health and social work (N). This grouping covers much, but not all of public sector production. Estimates of MFP for the UK for LMN between 1995 and 2008 show an annual average fall of 0.7 per cent, rather more than the estimate of a fall of 0.3 per cent a year for public service productivity presented in this article (see also Phelps 2010b).

However, the LMN productivity estimates differ in their construction from those presented in this article in several ways:

- LMN includes areas that are not covered by estimates in this article, such as private healthcare, private education and veterinary services

- the LMN estimates are based on National Accounts output data and therefore do not include the quality adjustments in this article

- the output of LMN is measured by value-added, whereas the output of publicly-funded services, because it is a component of final spending not an industrial grouping, is measured by gross output (value-added plus intermediate consumption)

- the input measure used in calculating LMN productivity is a weighted average of input of (quality-adjusted) labour and capital services. It excludes intermediate inputs, because it is a value-added measure not a gross output measure

- labour input in the LMN estimates is quality adjusted for skill and experience using qualifications and gender as proxies, following Eurostat conventions, whereas the estimates in this article quality adjust by distinguishing different types of job and weighting by the job specific labour costs

- the LMN estimates begin in 1995, not 1997

For all these reasons the estimates of productivity in this article are not directly comparable with those of LMN. Moreover it can be shown that value-added productivity growth moves proportionately more than gross output productivity growth, the concept measured in this article. Both the gross output MFP growth estimates for public service delivery of this article and the valueadded MFP growth estimates for LMN show negative growth. The two sets of estimates are therefore broadly consistent with each other, given the differences in concept and coverage between the measures outlined above. 
People also want to compare public sector performance against private sector performance. This is not easy to do. The best approximation to a definition of the private sector is the market sector, that subgroup of industries which sells its output at economically meaningful prices. Some of these industries do in fact provide public services, for example the independent treatment centres providing operations for the NHS. So there is some overlap in coverage between the market sector and the public service provision analysed in this article. More importantly, market sector MFP growth estimates are only available on a value-added basis, using labour inputs quality adjusted as with sectors LMN, described above. And value-added MFP measures, as noted above, move proportionately more than gross output measures. The issues in comparing different estimates of productivity produced by the Office for National Statistics are discussed further in Phelps (2010b).

What Long and Franklin (2010) shows is that market sector multifactor productivity growth grew by 1.0 per cent a year over the period 1995 to 2008. However not all sectors grew at the same rate. Sector OPQ had the largest fall in productivity, an annual average fall of 1.9 per cent. OPQ does include some public sector activities, including refuse collection and libraries and museums. But it also includes a substantial amount of market sector activity, such as hair-dressers, funeral services and laundry services, as well as culture and entertainment and sport (including television and films) and domestic service. OPQ therefore includes a lot of personal services, in which, because of their personal nature, it may be difficult to increase multi-factor productivity.

Two other sectors have also show negative multi-factor productivity growth over the period 1995 to 2008. These are section $\mathrm{H}$, hotels and restaurants, and section $\mathrm{K}$, real estate, renting and business activities, which includes estate agents, letting agents, consultancy, employment agencies and the like. These are all market sector, but also areas where personal service is important, which may make conventionally measured multi-factor productivity growth difficult to achieve. Multi-factor productivity fell by an annual average of 1.3 per cent in section $\mathrm{H}$, and by 0.3 per cent in section $\mathrm{K}$.

\section{Conclusion}

Over the whole period 1997 to 2008 total public service output has increased substantially. This largely reflects the increase in the volume of inputs, where growth was particularly high between 2002 and 2004. But the growth in inputs exceeded the growth in output, so over the whole period productivity has not recovered to its 1997 level.

After rising in 2006 and 2007 total public service productivity is estimated to have fallen in 2008 . This was not because of a fall in output growth. Output growth in fact rose in 2008 compared to 2007. But input growth increased more.

\section{Notes}

1. In all tables and charts, mean refers to the geometric mean 
2. The POS category consists of Fire, Courts, Probation and Prisons. Police has been separated, as its output is measured simply by its inputs.

3. The 'Other' category consists of General Public Services, Economic Affairs, Environmental Protection, Housing \& Community Amenities and Recreation, Culture \& Religion.

4. Higher Education also falls in the NPISH sector, but has more diverse sources of funding. Our estimates exclude Higher Education.

5. These indirect measures are not necessarily the same as measures of real spending, which are derived by dividing spending on an input by an overall price index (such as the GDP deflator or the Consumer Price Index).

6. The measure reported here is not the same as labour productivity growth, which only measures the growth in output per person (or person hour) employed. Output per person (or person hour) may increase because of increases in the amount of capital services or intermediate consumption per person (or person hour) or improvements in the quality of the labour input, rather than through improvements in efficiency. Moreover, since non-labour inputs typically grow rather than decline, growth in this multi-factor measure of productivity will usually be less than growth in labour productivity.

\section{Contact}

elmr@ons.gov.uk

\section{References}

Atkinson T (2005) 'Atkinson Review: Final Report: Measurement of government output and productivity for the National Accounts', Palgrave Macmillan: Basingstoke.

Baird A (2010) 'Measuring the Output of the Probation Service', Office for National Statistics, available at: www.statistics.gov.uk/cci/article.asp?ID=2454

Baird A and Rowlinson A (2010) 'Measuring the Output of the Prison Service', Office for National Statistics, available at: www.statistics.gov.uk/cci/article.asp?ID=2461

OECD (2001) 'Measuring Productivity', OECD Manual, available at: www.oecd.org/dataoecd/59/29/2352458.pdf

Long and Franklin (2010) 'Multi-factor productivity: estimates for 1994 to 2008', Economic \& Labour Market Review, vol 4 no. 9 pp 67-72, available at www.statistics.gov.uk/cci/article.asp?ID=2576

Penaloza M, Wild R, Hardie M and Mills K (2010) 'Public Service Output, Input and Productivity: Healthcare', Office for National Statistics, available at: www.statistics.gov.uk/cci/article.asp?ID=2382

Phelps M and Munro F (2009) 'Total Public Service Output and Productivity', Office for National Statistics, available at: www.statistics.gov.uk/cci/article.asp?ID=2212 
Phelps M (2010a) 'Measuring the Output of Children's Social Care: an alternative method for looked after children', Office for National Statistics; available at:

www.statistics.gov.uk/cci/article.asp?|D=2476

Phelps M (2010b) 'Comparing the different estimates of productivity produced by the Office for National Statistics', Office for National Statistics; available at:

www.statistics.gov.uk/cci/article.asp?ID=2391

Kamarudeen S (2010) 'Measuring Defence Labour', Office for National Statistics, available at: www.statistics.gov.uk/cci/article.asp?ID=2379

Wild R, Munro F and Ayoubkhani D (2009) 'Public Service Output, Input and Productivity:

Education, Office for National Statistics, available at: www.statistics.gov.uk/cci/article.asp?ID=2327 